\title{
PENDIDIKAN DAN LATIHAN AKUNTANSI BAGI PELAJAR DAN MAHASISWA MELALUI PPUPIK PUSAT PELATIHAN AKUNTANSI UNIVERSITAS PGRI PALEMBANG
}

\author{
Zahruddin \\ Fakultas Keguruan dan Ilmu Pendidikan Universitas PGRI Palembang, Jln Jenderal A. \\ Yani Lorong Gotong Royong 9/10 Ulu Palembang, 30257, Indonesia \\ Email: zhodsay@gmail.com
}

\begin{abstract}
ABSTRAK
Pendidikan dan latihan akuntansi bagi pelajar dan mahasiswa melalui PPUPIK Pusat Pelatihan Akuntansi Universitas PGRI Palembang ini membidik peserta didik dengan 4 target sarasan antara lain siswa SMA/MA, siswa SMK, mahasiswa dan umum. Pelatihan akuntansi dilaksanakan secara teori dan praktik, baik ilmu akuntansi maupun komputer akuntansi. Sistem pengenalan yang telah dilakukan dengan melibatkan mahasiswa Duta Accounting Edu dan HMPS Pendidikan Akuntansi dengan mendatangi sekolah dan kampus di kota Palembang untuk mempromosikan dan/atau mengadakan kerjasama. Pelaksanaan kegiatan juga dipublikasikan di media massa, baik koran cetak harian maupun online. Pelaksanaan kegiatan yang telah dilakukan dengan dua kelas yaitu kelas pagi jam belajar 08.00-12.00 WIB. Sedangkan kelas siang jam belajar 12.00 - 16.00 WIB. Pelatihan akuntansi yang dilakukan dibagi ke dalam 4 kelas, yaitu akuntansi perusahaan jasa, akuntansi perusahaan dagang, akuntansi perusahaan manufaktur dan akuntansi komputer (MYOB dan Accurate). Pada gelombang 1 (Februari - Maret 2018) pesertanya pelajar SMA, SMK dan MA yang berjumlah 149 orang, pada gelombang 2 (Mei - Juni 2018) pesertanya mahasiswa dari berbagai perguruan tinggi yang berjumlah 149 orang dan pada gelombang 3 (Agustus - September 2018) pesertanya adalah siswa SMA, SMK dan MA yang berjumlah 50 orang. Setelah menempuh pembelajaran 12-16 pertemuan dilaksanakan ujian akhir, bagi yang dinyatakan lulus diberikan sertifikat. Untuk tenaga pengajar, selain dosen Prodi Pendidikan Akuntansi dan dosen Prodi Akuntansi FE Universitas PGRI Palembang, juga melibatkan alumni dan mahasiswa yang berprestasi tinggi. Pengajar yang berasal dari mitra adalah Kursus akuntansi Prospek. Pengajar tamu diundang untuk kuliah umum dan suplemen.
\end{abstract}

Kata kunci: akuntansi, pelatihan, teori, praktek 


\begin{abstract}
Accounting education and training for students and college through PPUPIK, target this Accounting Training Center at the University of Palembang PGRI have 4, there are Senior high school/Islamic School students, vocational students, college and the general public. Accounting training is implemented in theory and practice, both accounting and computer accounting. The recognition system has been carried out by involving college of Edu Accounting Ambassadors and Accounting Education study program by visiting schools and campuses in Palembang to promote and / or establish cooperation. The activities were also published in the mass media, online and newspapers. The implementation of the activities that have been done with two classes, morning study class at 08.00 a.m-12.00 a.m., afternoon study class is 12.00 a.m-16.00 p.m. Accounting training conducted is divided into 4 classes, there are service company accounting, trading company accounting, manufacturing accounting and computer accounting (MYOB and Accurate). In phase 1 (February - March 2018) there were 149 participants from Senior high school, vocational School and Islamic School students, on phase 2 (May - June 2018) the participants were students from various universities totaling 149 people and on phase 3 (August - September 2018) the participants were 50 Senior high school, vocational School and Islamic School students. After studying 12-16 meetings, the final examination is conducted for those who have passed the certificate given. For teacher, besides the lecturer in Accounting Education Study Program and lecturer in Accounting Study ProgramUniversity of PGRI Palembang, and also involves brainy alumni. Teachers who come from partners are Prospect accounting courses. Guest lecturers are invited to public lectures and supplements.
\end{abstract}

Key words: accounting, training, theory, practice

\section{PENDAHULUAN}

Pelajar dan mahasiswa adalah kaum intelektual "Agent of Change" dalam sejarah peradaban manusia, pewaris negeri yang akan membangun bangsa dimasa depan. "Iron Stock" dalam mewujudkan kemajuan bangsa dan sumber daya manusia yang akan mengelola sumber daya alam yang tersedia. "Social Control" dalam pembangunan bangsa, pelajar dan mahasiswa merupakan kader potensial atau calon-calon pemimpin masyarakat di segala bidang, dan harapan umat di masa yang akan datang.

Sebagaimana kita ketahui, bahwa siswa tingkat lanjutan atas dalam menempuh pendidikannya dikelompokkan menjadi 3 macam tempat, yaitu Sekolah Menengah Atas (SMA), Sekolah Menengah Kejuruan (SMK) dan Madrasah Aliyah (MA). Pada setiap jenjang pendidikan tersebut memiliki tujuan dan kurikulum yang berbeda-beda.Ada banyak kemiripan kurikulum antara SMA dan MA, namun tentu cukup banyak perbedaan dengan SMK.Karena pendidikan di SMK telah dikhususkan pada bidang ilmu dan keterampilan tertentu yang juga dimaksudkan untuk mempersiapkan tenaga kerja siap pakai di dunia usaha atau dunia kerja. Namun demikian setiap sekolah dan/atau guru dalam merencanakan dan melaksanakan 
kurikulum tetap harus berpedoman pada Permendikbud Republik Indonesia Nomor 69 Tahun 2013 tentang Kerangka Dasar dan Struktur Kurikulum Sekolah Menengah Atas/Madrasah Aliyah dan Permendikbud Republik Indonesia Nomor 70 Tahun 2013 tentang Kerangka Dasar dan Struktur Kurikulum Sekolah Menengah Kejuruan/Madrasah Aliyah Kejuruan.

Sedangkan lulusan SMA dan MA umumnya dipersiapkan untuk melanjutkan ke jenjang perguruan tinggi. Pada saat yang sama perguruan tinggipun menawarkan berbagai program studi yang dapat dipilih oleh lulusan-lulusan SMA dan MA tersebut. Salah satu program studi dimaksud adalah akuntansi, baik akuntansi murni yang bernaung di bawah Fakultas Ekonomi maupun Pendidikan Akuntansi yang bernaung di bawah Fakultas Keguruan dan Ilmu Pendidikan (FKIP). Fakta menunjukkan bahwa bidang akuntansi merupakan bidang yang banyak menjadi pilihan utama, baik di tingkat SMK bidang ekonomi dan bisnis maupun di tingkat perguruan tinggi.Pada sisi lainnya di perguruan tinggi umumnya bidang akuntansi menempati passing grade tertinggi di bidang ilmu sosial.

Pelajar dan mahasiswa banyak mengikuti tambahan belajar (les, kursus, dan sejenisnya) di luar jam belajar sekolah, termasuk materi akuntansi dan keuangan. Ini membuktikan bahwa mereka merasa belum mendapatkan pengetahuan dan keterampilan yang cukup dari guru dan dosen di sekolah/kampus mereka. Materi pelatihan dasar dasar keuangan meliputi cara mengelol sumber-sumber dana dan mengalokasikan dana tersebut secara efisien dan efektit dalam suatu kegiatan usaha atau bisnis (Haryono, 2018).

Kursus dan bimbel yang banyak ditemukan saat ini menyediakan kelas hanya untuk MIPA, MIPA dan Bahasa Inggris. Kursus akuntansi yang mengkhususkan pelajaran akuntansi di kota Palembang sangat jarang, yang kami ketahui hanya satu yaitu Kursus Prosfek. Pada kursus prosfek ini siswanya sebagian besar adalah mahasiswa PTN dan PTS jurusan/program studi akuntansi, sedangkan pada tingkat SLTA adalah siswanya adalah beberapa orang yang berasal dari SMK jurusan akuntansi.

Beranjak dari pemikiran di atas, maka kami dosen Program Studi Pendidikan Akuntansi, FKIP Universitas PGRI Palembang mengadakan kegiatan Program Pengembangan Usaha Produk Intelektual Kampus (PPUPIK) berupa "Pusat Pelatihan Akuntansi" sebagai bentuk pelaksanaan Tri Darma Perguruan Tinggi berupa Pengabdian kepada Masyarakat (PkM). Tidak sama dengan bimbel dan/atau kursus yang sudah ada selama ini, pusat pelatihan ini menyasar peserta pembelajaran dengan 4 target sarasan antara lain siswa SMA/MA, siswa SMK, mahasiswa dan umum (alumnus SLTA dan perguruan tinggi, pegawai, karyawan swasta, guru ekonomi/akuntansi dan sebagainya). Pelatihan akuntansi dilaksanakan secara teori dan praktik, baik ilmu akuntansi maupun komputer akuntansi. 
Kegiatan ini diharapkan akan memberi manfaat yang berguna bagi para peserta didik. Untuk jangka pendek diharapkan setelah mengikuti kegiatan ini peserta didik dari SMA/MA, SMK dan mahasiswa memiliki pengetahuan dan keterampilan yang cukup sebelum mendapatkan materi belajar/kuliah. Sedangkan untuk peserta didik umum, diharapkan nantinya mendapatkan pengetahuan dan keterampilan yang dapat memenuhi dan menyesuaikan berdasar kebutuhan dunia kerja. Selanjutnya untuk jangka panjang, diharapkan ketika siswa yang menjadi peserta didik telah memasuki dan menjalani pembelajaran di bangku kuliah bagi yang memilih jurusan/program studi pendidikan akuntansi tidak mengalami kesulitan mengikuti perkuliahan. Tidak kalah penting juga adalah piagam/sertifikat yang diperolehnya dari pelatihan ini dapat digunakan sebagai dokumen referensi dalam mencari lapangan kerja, khususnya tenaga di bidang pembukuan, kasir, keuangan dan sebagainya. Sedangkan bagi umum piagam/sertifikat dapat digunakan sebagai pendukung kenaikan pangkat/jabatan dan sebagainya.

\section{METODE}

Adapun pelaksanaan kegiatan pelatihan akuntansi dari PPUPIK Pusat Pelatihan Akuntansi dengan alur proses persiapan sampai pelaksanaan pelatihan akuntansi sebagaimana berikut:

\subsection{Waktu dan Tempat Pelaksanaan}

Waktu aktif dan efektif kegiatan PPUPIK Pusat Pelatihan Akuntansi ini dilaksanakan sejak bulan Februari 2018 hingga laporan kemajuan ini dibuat pada Agustus 2018. Proses pembelajaran (pelatihan teori dan praktek) dibagi dalam 2 sesi, yaitu:

a. Pagi : jam $08.00-12.00$ WIB

b. Siang : jam $12.00-16.00$ WIB

Sedangkan tempat pelaksanaan

di kampus Universitas PGRI

Palembang, khususnya di

Laboratorium Terpadu Universitas PGRI Palembang di Jalan Jenderal A. Yani Lorong Gotong Royong 9/10 Ulu Palembang. Adapun ruangan yang digunakan untuk acara pembukaan, kuliah umum, belajar teori dan praktek dan ujian akhir antara lain :

a. Aula Perpustakaan Lantai 5 Universitas PGRI Palembang

b. Aula Gedung C Lantai 3 FKIP Universitas PGRI Palembang

c. Aula Lantai 4 Laboratorium Terpadu (ruang 402 dan 406) Univ. PGRI Palembang

d. Laboratorium Komputer Akuntansi (ruang 401 dan 403) Lantai 4 Lab. Terpadu Universitas PGRI Palembang

e. Lab. Tax Center (ruang 302) Lantai 3 Lab. Terpadu UPGRI Palembang

f. Ruang Kuliah Gedung H Lantai 1 dan 2 Universitas PGRI Palembang

\subsection{Bahan Baku}

PPUPIK yang dilaksanakan adalah berupa jasa, yaitu jasa pelatihan akuntansi yang melibatkan siswa/siswi baik SMA/MA atau pun SMK, mahasiswa/i perguruan tinggi yang berada di dalam dan di luar 
lingkungan Universitas PGRI Palembang serta umum (guru ekonomi/akuntansi, pegawai, alumni, $\mathrm{dsb)}$ sebagai peserta/objek/klien dari kegiatan ini.

Adapun jenis klien (peserta didik) yang telah dikelola tahun pertama sampai dengan bulan Agustus 2018 sebagai berikut :

Gelombang 1 berjumlah 149 orang, dengan rincian sbb:

a. Akuntansi Perusahaan Jasa $=102$ orang (SMA,SMK,dan MA)

b. Akuntansi Perusahaan Dagang = 19 orang (SMK)

c. Akuntansi Komputer (MYOB) = 28 orang (SMK)

Pada gelombang 1 ini selain 149 siswa di atas, terdapat hampir 150 siswa jurusan Akuntansi kelas XII SMK Muhammadiyah 2 Palembang dan SMK Negeri 8 Palembang yang hanya mengikuti 4 pertemuan (2 minggu) pada kelas Komputer Akuntansi (program MYOB) dalam rangka mereka mempersiapkan diri mengikuti ujian kompetensi akhir (Ujian Nasional/UN) MYOB di sekolah masing-masing, mengingat gelombang 1 pelatihan akuntansi ini dimulai bertepatan dengan 2-3 minggu sebelum UN siswa kelas XII SMK berlangsung. Oleh karena itu mereka hanya membayar uang pendaftaran dan modul sebesar $\mathrm{Rp}$ 50.000,-. Dengan demikian 150 siswa peserta pelatihan ini tidak mengikuti ujian akhir pelatihan akuntansi (MYOB) ini, secara otomatis mereka tidak mendapatkan sertifikat kelulusan pelatihan ini.

Gelombang 2 berjumlah 149 orang, dengan rincian sbb:

a. Akuntansi Perusahaan Jasa b. Akuntansi Perusahaan Dagang

c. Akuntansi Perusahaan Manufaktur

d. Akuntansi Komputer (MYOB dan Accurate)

Gelombang 3 berjumlah 50 orang, dengan rincian sbb:

a. Akuntansi Perusahaan Jasa

b. Akuntansi Perusahaan Dagang

\subsection{Produksi}

Pada proses belajar mengajar di Pusat Pelatihan Akuntansi ini disiapkan buku panduan belajar berupa Modul untuk peserta yang akan mempermudah pembelajaran, baik untuk pembelajaran teori maupun praktek. Setelah dinyatakan lulus dari ujian, bagi yang lulus akan diberikan sertifikat. Sebagaiman target peserta selama 3 tahun, maka penyiapan modul dan sertifikat untuk tahun pertama adalah :

Gelombang 1

375 eksemplar modul dan 650 sertifikat

Gelombang 2 : 135 eksemplar modul

Gelombang 3 : $\quad 50$ eksemplar modul

Sarana yang telah dimiliki untuk berlangsungnya Pusat Pelatihan Akuntansi terdapat pada Gedung Laboratorium Terpadu 5 lantai, ini antara lain:

a. Ruang Kelas sebanyak 2 ruang (ruang 402 dan 406 lab auditorium di lantai 4).

b. Ruang komputer akuntansi sebanyak 2 ruang (ruang 401 dan 403 di lantai 4)

c. Ruang praktek Tax Center (ruang 302 di lantai 3)

d. Ruang Kantor Pusat Pelatihan Akuntans1(beanguranhasismater di 


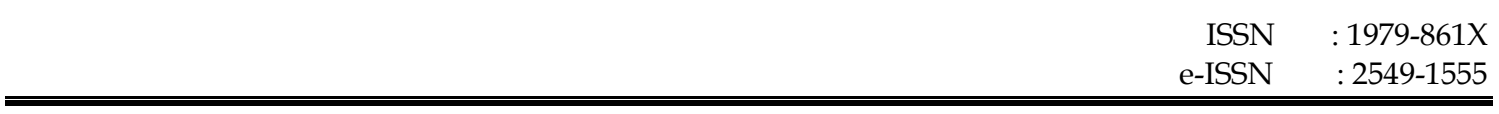

lantai 3, saat ini hanya ruang kosong yang belum digunakan)

e. Ruang Program Studi Pendidikan Akuntansi (Gedung c lantai 1)

Sedangkan sarana yang belum dimiliki untuk berlangsungnya Pusat Pelatihan Akuntansi ini adalah sarana dan prasarana untuk Ruang Kantor Pusat Pelatihan Akuntansi yang terletak di lantai 3 Laboratorim Terpadu dengan ukuran $4 \times 4$ meter. Layaknya sebuah kantor, sarana telah diadakan antara lain AC, meja dan kursi pengelola, meja dan kursi tamu, papan tulis, laptop, printer, dispenser, lemari dan sebagainya.

\subsection{Proses Produksi}

Sebagai kegiatan jasa proses produksi dimaksud adalah proses belajar mengajar (pendidikan dan latihan) yang dikomandoi oleh Anggota Tim Pelaksana Kegiatan PPUPIK, yaitu Neta Dian Lestari, S.Pd, MM yang bertanggung jawab terhadap jalannya proses pembelajaran. Alur produksi/proses belajar mengajar sebagaimana dapat digambarkan berikut ini:

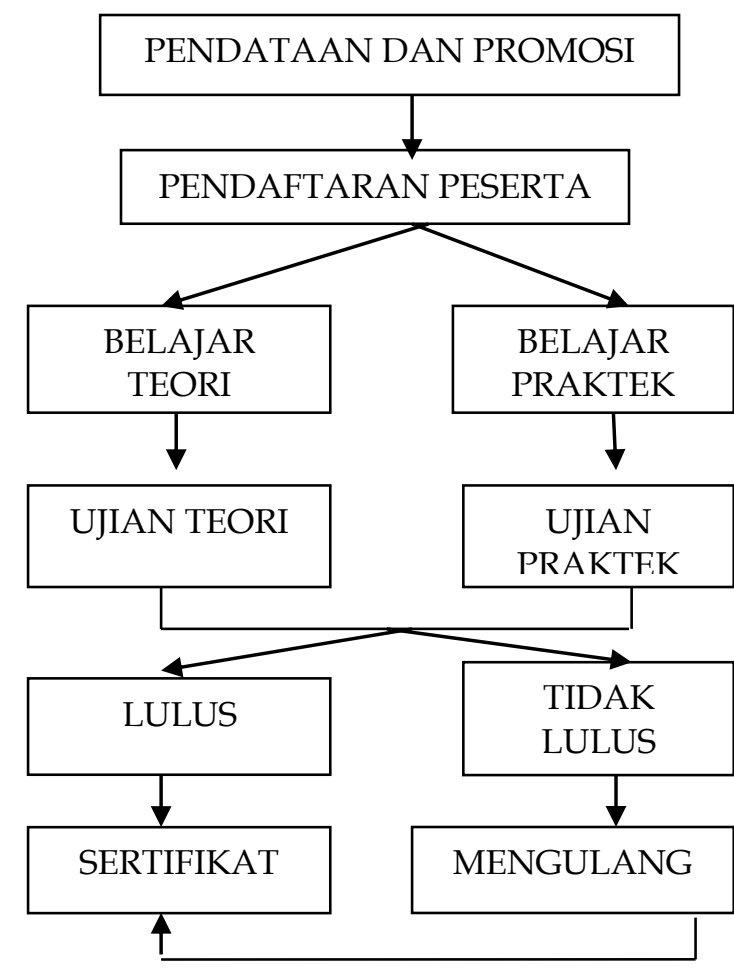

Gambar 1. Bagan Alur Proses Produksi (PBM) Pusat Pelatihan

Akuntansi

Pelaksanaan kegiatan Pusat Pelatihan Akuntansi akan dilakukan dengan dua kelas belajar yaitu:

- Kelas Pagi: jam belajar 08.00 - 10.00 WIB dan 10.00 - 12.00 WIB

Kelas ini ditujukan kepada peserta pelatihan yang waktu sekolah atau kuliahnya pada siang hari, sehingga sebelum pergi ke sekolah atau kampus pada pagi hari mereka dapat mengikuti pelatihan ini terlebih dahulu.

- Kelas Siang: jam belajar 12.00 14.00 WIB dan 14.00 - 16.00 WIB

Kelas siang ditujukan kepada peserta petihan yang waktu sekolah atau kuliahnya pada pagi hari, sehingga sepulang sekolah atau kuliah mereka dapat langsung mengikuti pelatihan akuntansi ini. 
Pengajaran yang dilakukan dibagi ke dalam 4 kelas tingkatan pembelajaran yaitu:

1. Tingkat Akuntansi Dasar

Membahas akuntansi secara teoritis dan praktek (siklus akuntansi) perusahaan jasa (Astuti, 2012). Sedangkan menurut Yadiati (2010) siklus akuntansi perusahaan jasa meliputi bukti transaksi , mencatat transaksi dalam jurnal umum sampai ayat jurnal pembalik.

2. Tingkat Akuntansi Menengah

Pada tingkat ini yang dipelajari adalah akuntansi perusahaan dagang. Akuntansi perusahaan dagang menurut Samryn (2012) terdiri dari siklus akuntansi perusahan dagang, neraca lajur dan laporan keuangan serta penutupan pembukuan. Akuntansi perusahaan dagang dengan buku jurnal khusus, buku pembelian, buku penjualan, buku penerimaan kas, buku pengeluaran kas dan buku umum (Mursyidi, 2010)

3. Tingkat Akuntansi Lanjutan

Akuntansi

Perusahaan manufaktur terdiri dari pengertian dan tujuan akuntansi biaya, ruang lingkup akuntansi biaya, pengertian biaya dan beban, biaya dalam perusahaan manufaktur, proses akuntansi biaya dan laporan keuangan dalam perusahaan industri (Mursyidi, 2010). Sedangkan menurut Sodikin (2012) mengatakan bahwa mempelajari akuntansi untuk perusahaan pemanufakturan terdiri dari lapoan keuangan, sistem penentuan harga pokok produk, sistem periodik dan sistem perpetual.

4. Tingkat Akuntansi Komputer

Untuk komputer akuntansi saat ini masih menggunakan program $M Y O B$ Accounting yang memperlajari proses setting awal, perancangan dan proses Chart of Account dan penghasilan saldo awal, transaksi pembelian, retur pembelian, pembayaran utang, transaksi penjualan, transaksi time billing, spend money, dam receive money (Prajitno, 2009).

Pada pusat pelatihan ini jumlah peserta di setiap kelas belajar berjumlah 25 - 30 orang dengan tujuan agar pembelajaran lebih efektif. Ruang belajar yang digunakan adalah ruang Auditorium I/402 dan ruang Auditorium II/406 lantai 4 Gedung Laboratorium Terpadu, dengan luas 4 x $8 \mathrm{~m}$ yang telah memiliki fasilitas lengkap (sebagaimana dapat dilihat pada photo-photo gedung dan fasilitas pada Bab 4 Kelayakan Perguruan Tinggi). Disamping itu juga disediakan kelas belajar komputer akuntansi yang pembelajarannya dilakukan di Laboratorium Komputer Akuntansi Prodi Pendidikan Akuntansi FKIP Universitas PGRI Palembang. Adapun lamanya pelatihan dilakukan 12-16 pertemuan, yang ditempuh selam 2 bulan per angkatan. Jumlah pertemuan 2 kali dalam 1 minggu dan lamanya belajar 2 jam per pertemuan.

Berikut ini photo proses pelatihan akuntansi, baik secara teori maupun praktek: 


\begin{tabular}{rrr} 
ISSN & $: 1979-861 X$ \\
e-ISSN & $: 2549-1555$ \\
\hline \hline
\end{tabular}
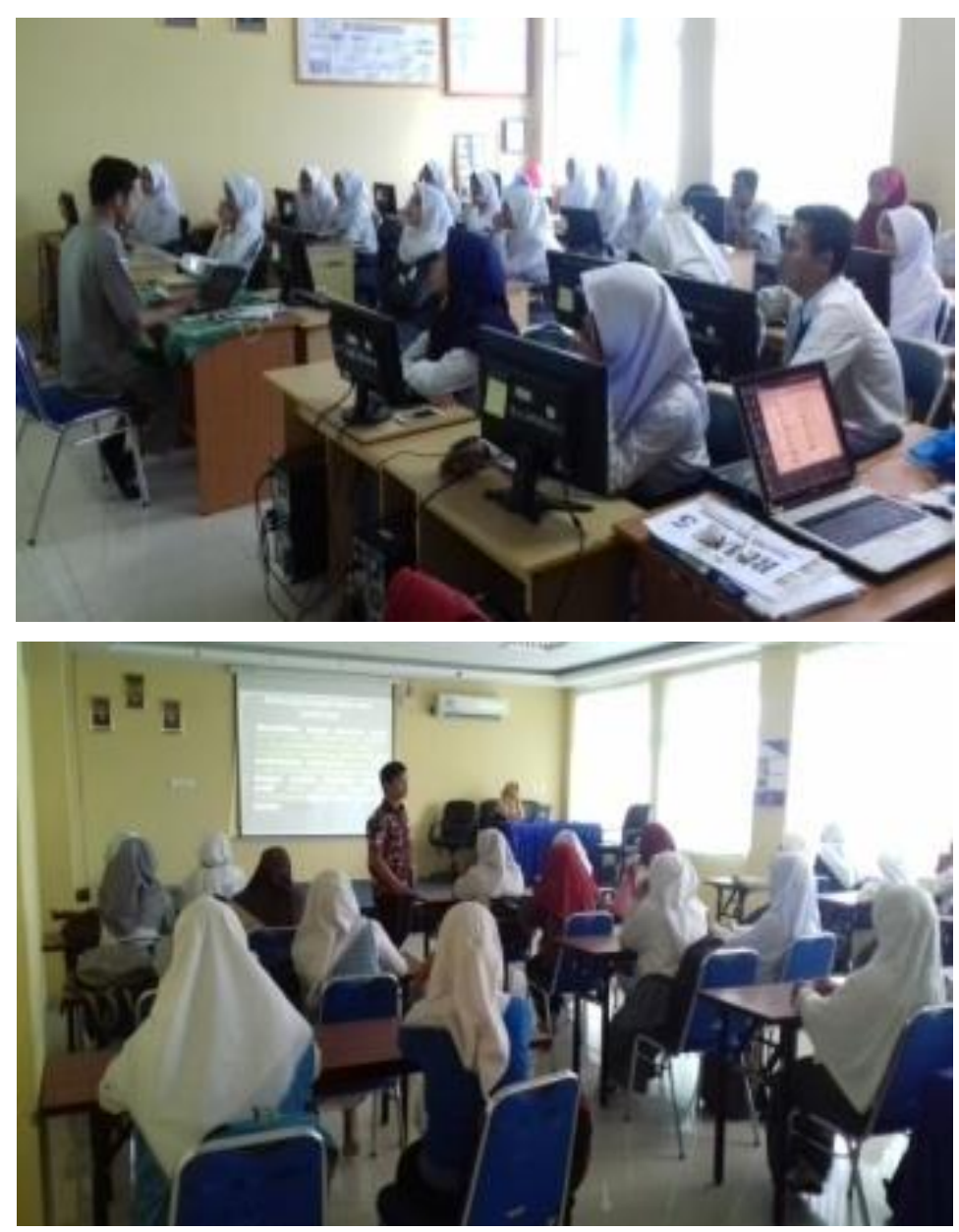

Gambar 2. Pelatihan Akuntansi Teori dan Praktek

\subsection{Manajemen}

Kegiatan Pusat Pelatihan Akuntansi ini akan dikelola oleh kelompok Dosen, alumni dan mahasiswa Program Studi Pendidikan Akuntansi FKIP Universitas PGRI Palembang. Kegiatan ini akan dipimpin langsung oleh Ketua Tim PPUPIK sekaligus sebagai Ketua
Prodi Pendidikan Akuntansi yang berfungsi sebagai Manajer dan bertanggung jawab langsung kepada Dekan FKIP Universitas PGRI Palembang. Berikut struktur organisasi PPUPIK Pusat Pelatihan Akuntansi: 


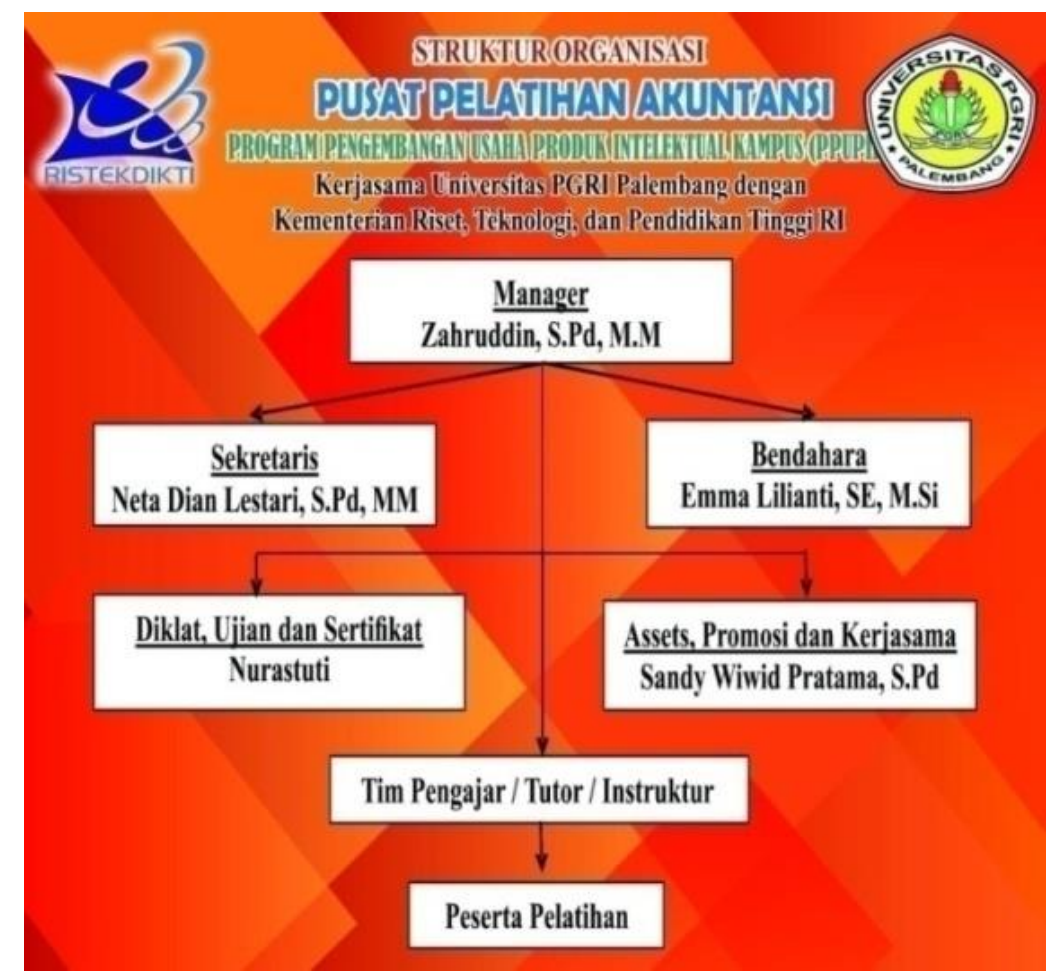

Gambar 3. Struktur Organisasi Pusat Pelatihan Akuntansi

Adapun tim Pengajar dari dosen Prodi Pendidikan Akuntnsi FKIP Universitas PGRI Palembang, pengajar dari dosen Program Studi Akuntansi Fakultas Ekonomi (FE) Universitas PGRI, mahasiswa Pengajar Pendamping/Asisten dengan prestasi akademik yang tinggi (IPK $\geq 3,5)$ serta untuk Tutor/Instruktur Alumni Prodi Pendidikan Akuntansi FKIP Universitas PGRI Palembang (yang Lulus dg Cum Laude). Selain itu terdapat 1 tutor/instruktur juga yang berasal dari mitra pelatihan akuntansi ini berdasarkan follow up Memorandum of Understanding (MoU) antara Universitas PGRI Palembang dengan Kursus Akuntansi Prospek.

Selanjutnya
Tutor/Instruktur
pembicara yang telah dilaksanakan

hingga gelombang 2 yang berasal dari eksternal kampus adalah:

1. Kgs. Abdul Rahman, SE (Kantor Pelayanan Pajak Pratama Ilir Timur Palembang)

2. Dr. Maya Panorama, M.Si, Ph.D (Dosen Fakultas Ekonomi dan Bisnis Islam/FEBI UIN Raden Fatah Palembang)

Sebagaimana disampaikan sebelumnya bahwa rencana produksi (production planning) bahwa peserta didik yang ditargetkan selama 3 tahun berturut-turut sebanya 200 orang, 300 orang dan 400 orang. Hal ini sesuai dengan target pangsa pasar yang dibidik pada setiap tahunnya. Sedangkan untuk pembukuan akuntansi (accounting bookkeeping), sebagaiman terdapat pada struktur organisasi PPUPIK di atas, akan ditempatkan satu orang sebagai bendahara yang direktut dari salah satu alumni terbaik. Setiap transaksi 
harus memiliki bukti-bukti transaksi, antara lain seperti kuitansi bukti pembayaran/pendaftaran peserta didik dan nota/faktur untuk transaksi pembelian dan penjualan barang tertentu. Semua transaksi harus dicatat dan dibukukan secara rapi dan lengkap, baik secara manual maupun dengan komputerisasi. Setiap periode pembelajaran selesai yang bekisar 2-3 bulan, maka bendahara membuat arus kas masuk dan keluar.

\subsection{Pemasaran}

Pemasaran/promosi dan kerjasama dikomandoi langsung oleh Ketua Tim, bersama 2 anggota tim. Anggota tim pelaksana kegiatan yaitu Emma Lilianti, SE, M.Si yang bertanggung jawab terhadap pemasaran / promosi kegiatan pelatihan akuntansi ke berbagai tempat sebagai sasaran peserta pelatihan dari program PPUPIK Ini. Pada pelaksanaan tugasnya bagian pemasaran dibantu 2 orang staf yang berasal dari alumni dan mahasiswa aktif.Selain itu promosi ke sekolahsekolah dan kampus-kampus dengan melibatkan mahasiswa "Duta Accounting Edu" dan mahasiswa yang tergabung dalam Himpunan Mahasiswa Program Studi Pendidikan Akuntansi (HMPS-PA) FKIP Universitas PGRI Palembang.

Pusat pelatihan akuntansi ini untuk awal mulanya akan diperkenalkan kepada siswa tingkat SLTA yaitu SMA, MA dan SMK. Awalnya dalam rencana pada tahun kedua pemasaran diperluas kepada mahasiswa berbagai perguruan tinggi negeri maupun swasta yang ada di kota Palembang, namun pada tahun pertama telah dilakukan juga promosi pelatihan akuntansi kepada mahasiswa. Sistem pengenalan yang akan dilakukan yaitu tim pengelola pusat pelatihan akuntansi akan mendatangi tempat-tempat sasaran pemasaran/promosi untuk melakukan promosi dan kerjasama dengan harapan pihak sasaran akan mengirimkan utusannya untuk ikut serta pada pusat pelatihan akuntansi ini. Selain sebagai utusan dari sekolah/perguruan

tinggi/perusahaan, peserta secara individu juga dapat mendaftar pada Pusat Pelatihan Akuntansi ini.

Saat melakukan pemasaran/ promosi sebagai daya tarik kami menyampaikan fasilitas yang akan diperoleh peserta pelatihan akuntansi nantinya berupa modul pembelajaran akuntansi, alat tulis, makanan dan minuman ringan, tutorial sofware komputer akuntansi, piagam/ sertifikat pelatihan akuntansi, workshop dan studi lapangan ke kantor pajak, bank, perusahaan,dll, informasi lapangan/lowongan kerja.

\subsection{Sumber Daya Manusia}

Murwaningsih

mengatakan bahwa dalam peningkatan kualitas sumber daya manusia, pendidikan menjadi faktor utama untuk penanaman dan pengembangan karakter. Oleh karena itu pengelola Pusat Pelatihan Akuntansi ini terdiri atas 5 orang Staf Pengajar Program Studi Pendidikan Akuntansi Fakultas Keguruan dan Ilmu Pendidikan (FKIP) dan Program Studi Akuntansi Fakultas Ekonomi (FE) Universitas PGRI Palembang, yang terdiri atas berbagai disiplin 
ilmu dengan tingkat pendidikan semuanya strata dua (S2). Mengingat 3 orang dosen adalah 1 orang ketua tim dan 2 anggota, maka 2 orang lainnya dilibatkan menjadi tim pelaksana kegiatan ini yaitu 2 orang mahasiswa dan alumni yang lulus dengan predikat cum laude yang selama kuliah aktif pada berbagai kegiatan organisasi kampus, seperti Himpunan Mahasiswa Program Studi Pendidikan Akuntansi (HMPS-PA) dan Badan Eksekutif Mahasiswa (BEM) dengan jabatan sekretaris dan bendahara, sehingga mereka telah memiliki pengalaman kemampuan dan skill administrasi dan keuangan untuk menjalankan tugasnya. Pada kegiatan PPUPIK ini juga dilibatkan 8 orang mahasiswa Prodi Pendidikan Akutansi FKIP Universitas PGRI Palembang sebagai pengajar/asisten, yang selain aktif dalam berorganisasi mereka juga mahasiswa-mahasiswa yang berprestasi tinggi dengan ratarata IPK 3,5. Dengan demikiani secara penguasaan keilmuan, iptek dan skills mereka semua sudah paham dan menguasai teknis pelaksanaan kegiatan pelatihan akuntansi ini.

Pada tahap awal usaha Pusat Pelatihan Akuntansi ini, memberikan pengeluaran dan/atau kompensasi bagi staf pengelola disesuaikan dengan kemampuan usaha. Untuk 2 orang staf diberi transport Rp 25.000,per hari, juga diberi fasilitas makan siang melalui katering dan pulsa paket bulanan. Untuk honor para pengajar/tutor/instruktur sebagai pengajar setiap pertemuan (2 jam) diberikan honornya $\mathrm{Rp} 75.000$,- untuk dosen, Rp 50.000,- untuk alumni dan Rp 40.000,- untuk mahasiswa. sampai
Rp 35.000,- per jam. Para pengajar juga diberikan kompensasi uang transport dan uang makan.

\subsection{Sarana dan Prasarana}

Sarana dan prasarana yang telah dimiliki untuk berlangsungnya Pusat Pelatihan Akuntansi terdapat pada Gedung Laboratorium Terpadu yang terdiri dari 5 lantai, ini antara lain:

a. Ruang kelas sebanyak 2 ruang (ruang 402 dan 406 lab auditorium di lantai 4).

b. Ruang laboratorium komputer akuntansi 2 ruang (ruang 401 dan 403 di lantai 4)

c. Ruang praktek Tax Center (ruang 302 di lantai 3)

d. Ruang Kantor Pusat Pelatihan Akuntansi (berukuran $4 \times 4$ meter di lantai 4,di samping Lift)

e. Alat tulis kantor (ATK), seperti Papan tulis, alat tulis, penghapus dsb

f. Laptop, layar slide, infokus/lcd, AC, pengeras suara dan sebagainya.

Selain itu juga terdapat sarana dan prasarana pendukung lainnya untuk mendukung berlangsungnya kegiatan pelatihan akuntansi ini, khususnya untuk acara pembukaan, kuliah umum dan ujian akhir yaitu :

a. Ruang Program Studi Pendidikan Akuntansi (Gedung E lantai 1)

b. Aula Perpustakaan Lantai 5 Universitas PGRI Palembang

c. Aula Gedung C lantai 3 FKIP Universitas PGRI Palembang

d. Ruang Kuliah lantai 1 dan 2 Gedung $\mathrm{H}$ Universitas PGRI Palembang. 


\subsection{Finansial}

Sebagaimana dalam ketentuan PPUPIK Kemenristekdikti dalam hal ini memberikan anggaran yang dialokasikan tahun pertama sebesar Rp 150.000.000,- dimana pencairan tahap pertama pada bulan Juni 2018 sebesar 70 \% yaitu Rp 105.000.000,-Selain itu terdapat dana pendamping dari Universitas PGRI Palembang sebesar Rp 40.000.000,- dalam bentuk in kind. Kedua sumber dana tersebut menjadi modal awal dalam melaksanakan program PPUPIK berupa Pusat Pelatihan Akuntansi ini.

Pada tahun pertama ini dana digunakan untuk memulai awal berdirinya Pusat Pelatihan Akuntansi. Sejak tahun pertama hingga tahun ketiga ditargetkan dan diharapkan mampu menghasilkan (produktif) sehingga dapat memberikan persentase kontribusi yang dapat diberikan kepada Universitas PGRI Palembang (income generating). Peserta pelatihan yang dikenakan biaya modul pembelajaran sebesar Rp 50.000,- dan biaya pembelajaran sebesar Rp 150.000,- untuk tingkat pelajar SMA, SMK dan MA dan Rp 200.000,- untuk tingkat mahasiswa. Setidaknya sisa hasil usaha yang juga dapat meningkatkan kesejahteraan pengelola dan para pengajar (instruktur atau tutor).

\section{HASIL DAN PEMBAHASAN}

Dengan telah berdirinya Unit Usaha "Pusat Pelatihan Akuntansi" di FKIP Universitas PGRI Palembang yang merupakan cikal bakal dari Program Pengembangan Usaha Produk Intelektual Kampus (PPUPIK), maka secara resmi telah dimulainya operasional usaha jasa berupa pelatihan akuntansi ini yang berlokasi di Laboratorium Terpadu Lantai 3 dan 5 Universitas PGRI Palembang di Jalan Jenderal A. Yani Lorong Gotong Royong 9/10 Ulu Palembang. Beberapa tahun terakhir kegiatankegiatan sejenis pelatihan akuntansi yang dilaksanakan oleh dosen dan mahasiswa melalui HMPS Pendidikan Akuntansi dilaksanakan secara parsial dan insidental, maka dimulai tahun 2018 pelaksanaannya dilaksanakan secara terintegral dan terus menerus dibawah koordinasi unit usaha Pusat Pelatihan Akuntansi FKIP Universitas PGRI Palembang ini.

Untuk tahun pertama 2018 ini, kegiatan usaha di unit usaha Pusat Pelatihan Akuntansi FKIP Universitas PGRI Palembang ini terdapat 5 bidang, sebagaimana tergambar pada berikut ini:

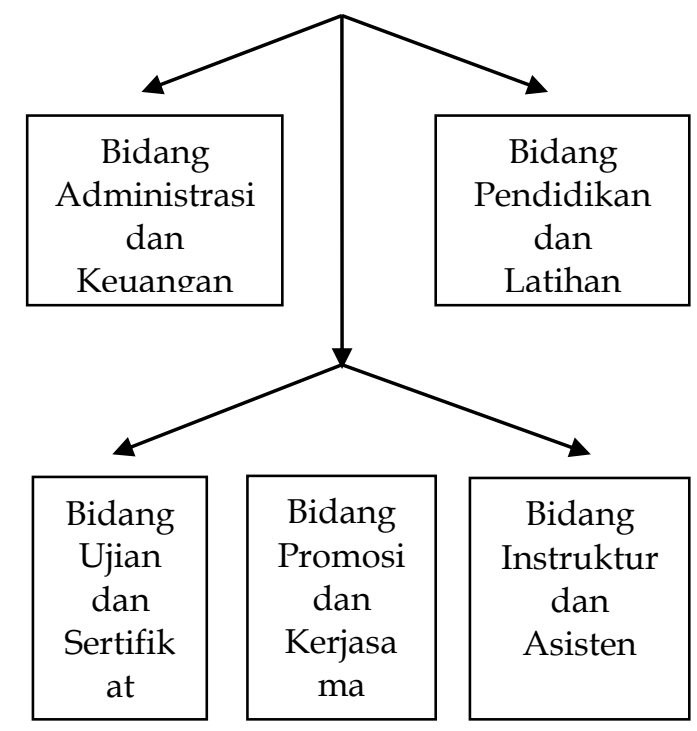

Gambar 4. Unit Usaha Pusat Pelatihan Akuntansi 
Berikut hasil yang dicapai berdasarkan bidang usaha sesuai dengan bidang masing-masing antara lain:

1. Bidang Administrasi dan Keuangan: Depi Pramika, S.Pd, M.Si

Bidang administrasi dan keuangan telah menghasilkan uang masuk dari peserta yang mengikuti pelatihan akuntansi ini sebesar $\mathrm{Rp}$ 84.550.000,- dengan rincian pemasukan bersumber dari :

Gelombang 1 :

149 orang $\times \mathrm{Rp} 200.000,-=\mathrm{Rp}$ 29.800.000,-

Gelombang 1 (modul saja)

150 orang $\times \operatorname{Rp} 50.000,-=$ 7.500.000,-

Gelombang 2 :

149 orang $\times \mathrm{Rp} 250.000,-=R p$ 37.250.000,-

Gelombang 3 :

50 orang $\times$ Rp 200.000,- $=\quad R p$ 10.000.000,-

2. Bidang Promosi dan Kerjasama: Sandy Wiwid Pratama, S.Pd
Bidang promosi dan kerjasama, menghasilkan peserta pelatihan setiap gelombang antara lain gelomban1, 2 dan 3 masing-masing sebanyak 300 siswa, 150 mahasiwa dan 50 siswa. Selain itu menghasilkan 10 Memorandum of Agrement (Perjanjian Pelaksanaan Kerjasama dengan 10 sekolah di kota Palembang, 1 lembaga kursus akuntansi dan 1 perusahaan rental fotocopy

3. Bidang Pendidikan dan Latihan: Erma Yulaini, S.Pd, M.Si

Bidang pendidikan dan latihan, telah menghasilkan modul belajar untuk peserta pelatihan antara lain berupa:

1. Modul Akuntansi Perusahaan Jasa

2. Modul Akuntansi Perusahaan Dagang

3. Modul Akuntansi Perusahaan Manufaktur

4. Modul Akuntansi Komputer (MYOB)

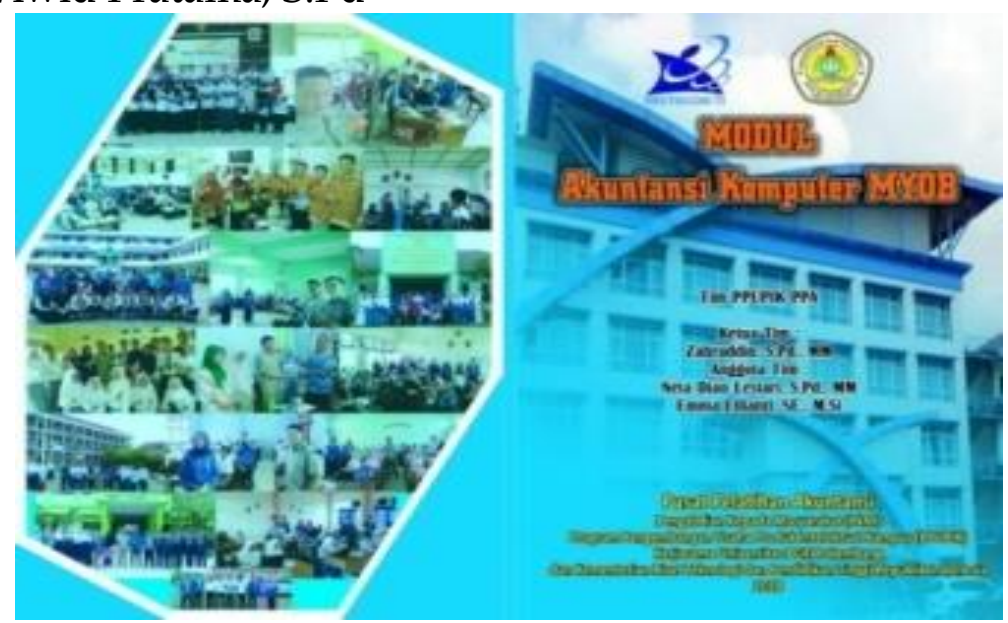



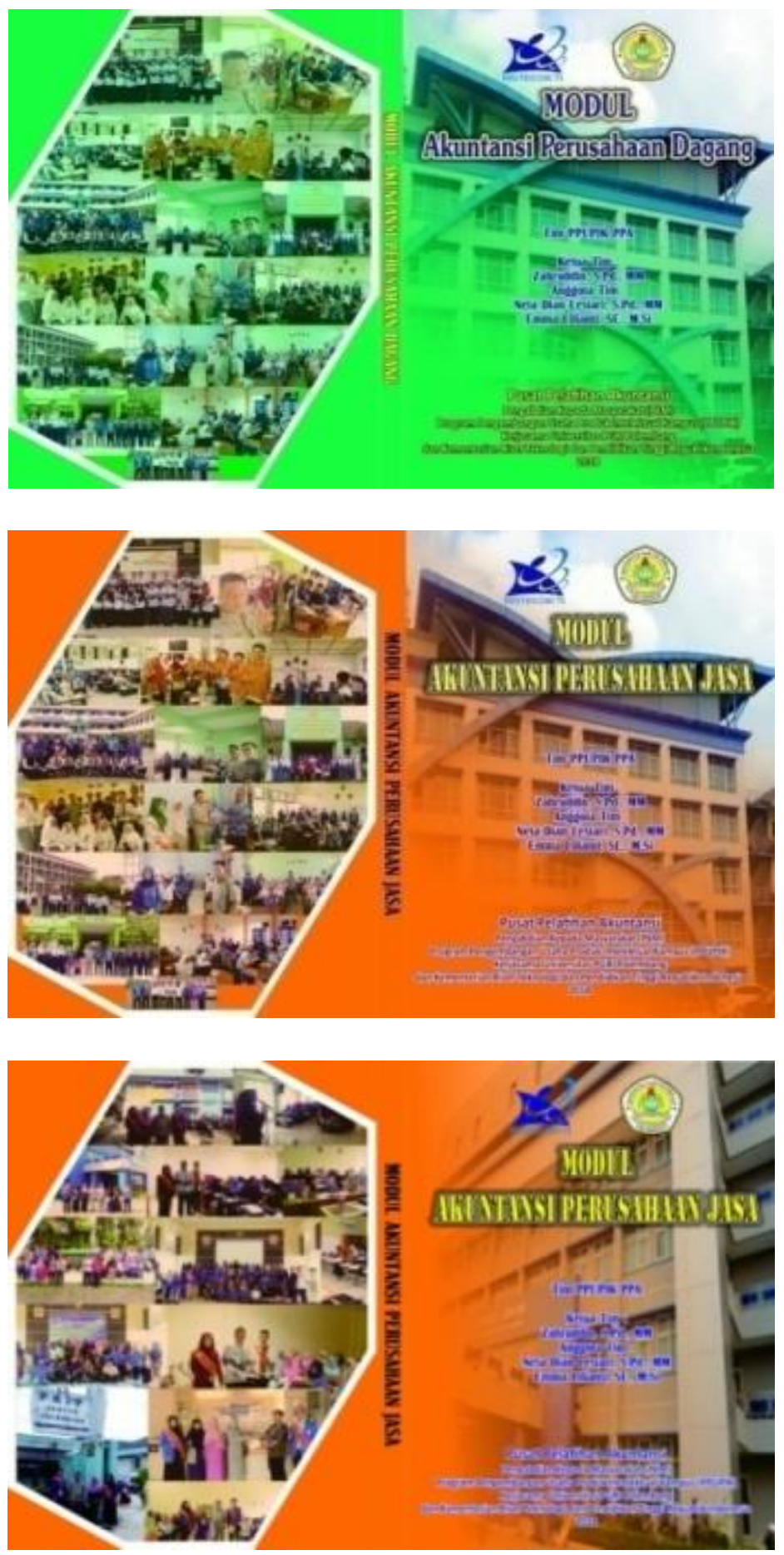

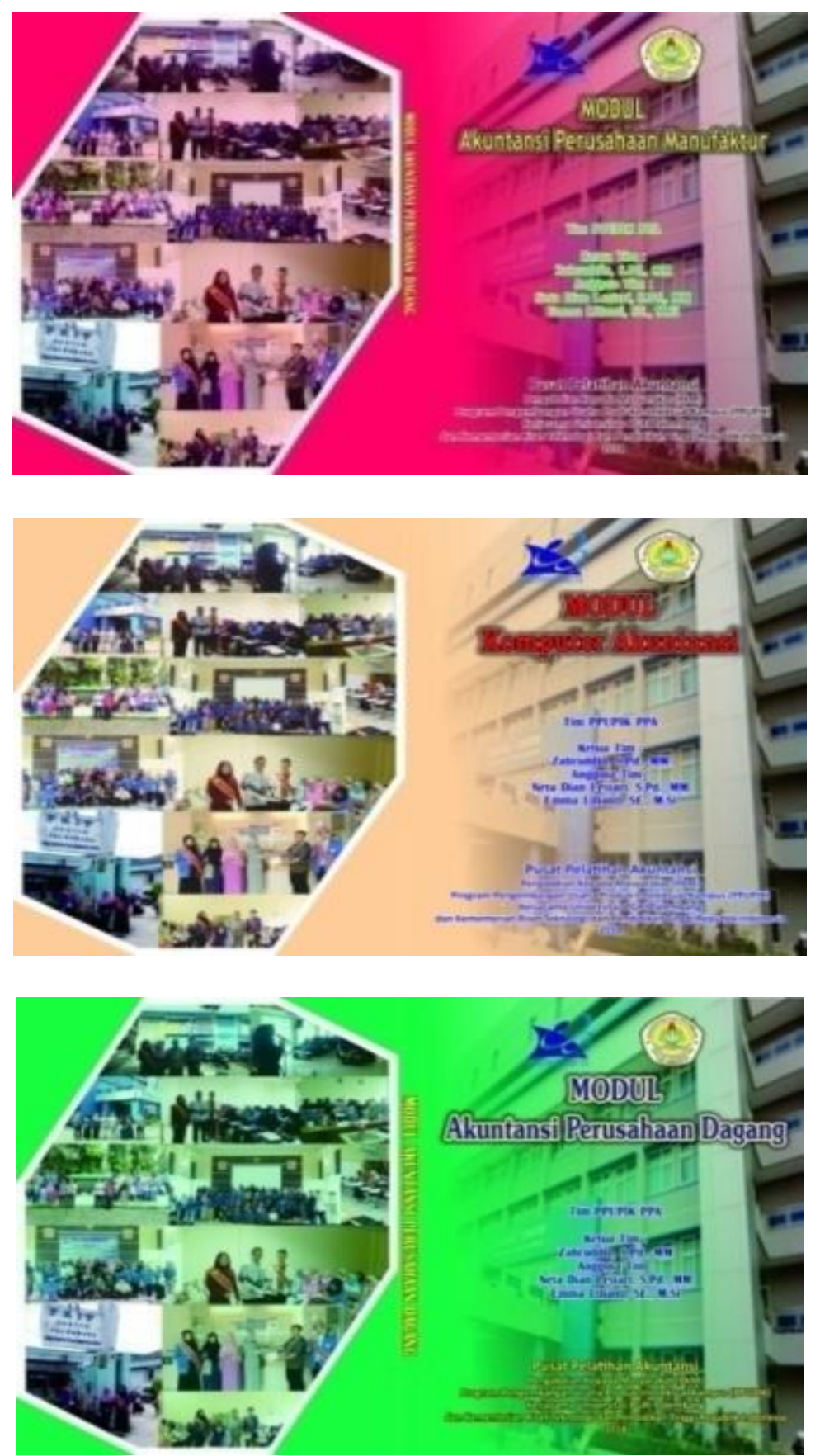

Gambar 5. Modul-Modul yang Digunakan pada Pelatihan Akuntansi memberikan dampak cukup

Dari segi peserta, proses signifikan dalam peningkatan hasil pendidikan dan latihan yang diikuti belajar pada mata kuliah akuntansi oleh para pesert telah memberikan yang mereka ampu bersamaan dampak/manfaat atau pengaruh dengan pelatihan akuntansi ini. dalam menunjang peningkatan hasil Evaluasi tentang pengetahuan, belajar mereka di sekolah pada mata keterampilan, sikap dan prilaku serta pelajaran ekonomi/akuntansi. Demikian juga bagi mahasiswa, telah pembelajaran tersebut penting karena 
keberhasilan dari tahapan berikutnya (Juanda, 2011).

Berdasar pengolahan data dengan membandingan hasil belajar mata pelajaran ekonomi/akuntansi siswa pada raport antara sebelum mengikuti pelatihan dengan setelah mengikuti pelatihan (bagi siswa) dan dengan membandingkan hasil belajar mata kuliah akuntansi pada Kartu Hasil Studi (KHS) antara sebelum mengikuti pelatihan dengan setelah mengikuti pelatihan (bagi mahasiswa), rata-rata mengalami peningkatan. Sebagai gambaran lengkap, berikut pengaruh pada hasil belajar siswa di sekolah untuk 149 siswa SMA, SMK dan MA peserta gelombang 1 :

Tabel 1. Pengaruh Terhadap Hasil Belajar di Sekolah (Peserta Gelombang 1)

\begin{tabular}{|c|c|c|c|}
\hline No & $\begin{array}{l}\text { Jumlah } \\
\text { Siswa }\end{array}$ & Persentase & Pengaruh \\
\hline 1 & 5 orang & 3,36 & Menurun \\
\hline 2 & 13 orang & 8,72 & Tetap \\
\hline 3 & 83 orang & 55,70 & $\begin{array}{l}\text { Naik 0,1 } \\
\text { sampai } \\
1,0\end{array}$ \\
\hline 4 & 31 orang & 20,81 & $\begin{array}{l}\text { Naik } 1,1 \\
\text { sampai } 2\end{array}$ \\
\hline 5 & 17 orang & 11,41 & Naik $>2$ \\
\hline
\end{tabular}

Berdasarkan data tersebut di atas, diketahui bahwa sebanyak 131 siswa peserta pelatihan akuntansi (sebesar 87,92 persen) nilai pelajaran ekonomi/akuntansi pada raport sekolah mengalami peningkatan, yang dikelompokkan ke dalam 3 jenis peningkatan yaitu 0,1 sampai 1,0, 1,1 sampai 2 dan lebih dari 2. Data juga menunjukkan bahwa memang tidak semua nilai siswa di raport mengalami peningkatan, ada sebanyak 18 siswa (sebesar 8,72 persen) nilainya tetap seperti sebelumnya. Bahkan terdapat 5 siswa (sebesar 3,36 persen) justru nilainya di sekolah mengalami penurunan. Mereka yang dalam kategori nilai tetap dan menurun ini, berdasarkan analisis absensi kehadiran memang tidak mencapai $75 \%$. Berdasarkan rekapitulasi daftar nilai ujian akhir pelatihan akuntansi, siswa pada kelompok itu mendapatkan nilai di bawah kategori cukup (kurang dari 60). Adapun tindak lanjut dari tim dan staf PPUPIK Pusat Pelatihan Akuntansi terhadap mereka yang berada pada kategori ini, diberikan perlakukan sistem remedi (belajar dan ulangan perbaikan) sampai mencapai hasil belajar di atas 60 .

Sedangkan pengaruh hasil belajar mahasiswa di kampus pada mata kuliah akuntansi untuk 149 peserta mahasiswa gelombang 2 sebagai berikut:

Tabel 2. Pengaruh Terhadap Hasil Belajar di Kampus (Peserta Gelombang 2)

\begin{tabular}{cccl}
\hline No & $\begin{array}{c}\text { Jumlah } \\
\text { Siswa }\end{array}$ & Persentase & Pengaruh \\
\hline 1 & 7 orang & 4,70 & Menurun \\
2 & 10 orang & 6,71 & Tetap \\
3 & 132 orang & 88,59 & $\begin{array}{l}\text { Naik 0,1 } \\
\text { sampai }\end{array}$ \\
& & & $\begin{array}{l}1,0 \\
\text { Naik 1,1 } \\
4\end{array}$ \\
& -- & 0,00 & sampai 2 \\
5 & -- & 0,00 & Naik $>2$ \\
\hline
\end{tabular}

Berdasarkan data pada tabel di atas dapat diketahui sebanyak 132 mahasiswa (atau sebesar 88,59 persen) hasil belajar yang dilihat melalui Indeks Prestasi pada Kartu Hasil 
Studi (KHS) mengalami peningkatan pada rentang 0,1 sampai 1,0 . Walaupun demikian, terdapat 10 mahasiswa (sebesar 6,71 persen) hasil belajarnya tetap atau konstan. Demikian juga data menunjukkan bahwa terdapat 7 mahasiswa (sebesar 4,70 persen) justru hasil belajarnya mengalami penurunan. Faktor mahasiswa mengikuti pelatihan akuntansi ini memang bukanlah satusatunya faktor yang mempengaruhi peningkatan atau penurunan hasil belajar (Indek Prestasi) mereka, terdapat faktor lainnya yang tidak kami teliti pada kesempatan ini. Hal itu mengingat pada KHS mahasiswa terdapat mata kuliah lain selain akuntansi dan/atau sejenisnya, sedangkan nilai setiap mata kuliah ditampilkan hanya berupa simbol A, B, C, D dan E dengan bobot nilai 1 sampai 4. Sedangkan sebagaimana kita ketahui umumnya dosen dalam melakukan penilaian mengunakan skor 1 sampai 10, baik nilai tugas, ujian mid semester maupun ujian akhir semester. Pada print out KHS mahasiswa yang muncul adalah nilai akhir dengan bobot nilai 1 sampai 4 dan simbol A sampai E.

4. Bidang Ujian dan Sertifikat: Hendri Gunawan, M.Pd

Bidang ini telah melaksanakan ujian kepada peserta pelatihan akuntansi yang dinyatakan memenuhi syarat berdasar jumlah pertemuan minimal $75 \%$ kehadiran, yang secara otomatis mendapatkan sertifikat kelulusan dengan jumlah sebagai berikut:

Gelombang 1 : 149 siswa

Gelombang 2 : 149 mahasiswa

Gelombang 3 : 50 siswa

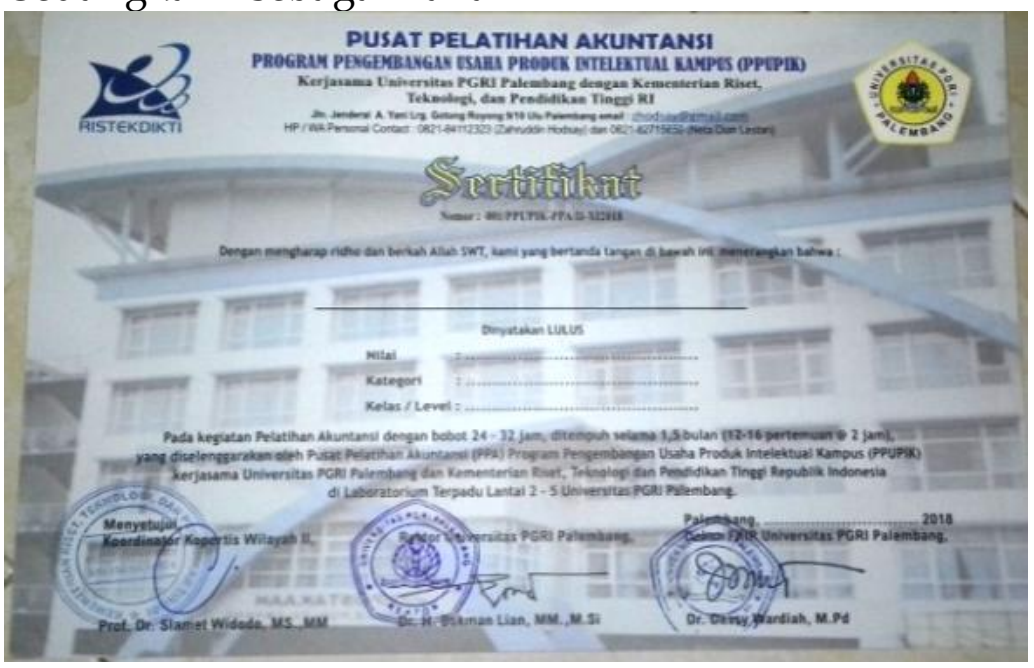

Gambar 6. Contoh Sertifikat bagi Peserta yang Lulus

Hasil belajar peserta pelatihan yang dinyatakan lulus dikelompokkan dalam beberapa kategori kelulusan dengan metode penilaian persentase, antara lain Cukup, Baik dan Sangat Baik. Atas dasar pedoman di bawah ini, maka

peserta pelatihan akuntansi yang dinyatakan lulus dikelompokkan dalam 3 kategori kelulusan yaitu :
a. Sangat Baik
(Nilai 85 - 100)
b. Baik
c. Cukup
(Nilai $75-84$ )
(Nilai 60 - 74) 
Hal itu sejalan dengan apa yang disampaikan Purwanto (2013: 103) bahwa cara menilai dengan persentase banyak dilakukan oleh guru dan dosen. Hal ini dianggap lebih mudah dan praktis. Disamping itu, jika nilainilai persen itu akan ditransfer ke dalam nilai huruf tidak perlu membuat tabel dan bersusah payah menghitungnya, tetapi tinggal mengonversikan dengan pedoman penilaian yang biasanya telah ada di perguruan tinggi masing-masing. Di samping itu, masing-masing penilai memiliki kesempatan untuk menyampaikan saran perbaikan bagi diri sendiri, teman sejawat maupun untuk sekolah (Wijayanti, 2013) Misalnya suatu perguruan tinggi mempunyai pedoman penilaian sebagai berikut :

Tabel 3. Contoh Pedoman Penilaian Hasil Belajar

\begin{tabular}{cccc}
\hline $\begin{array}{c}\text { Tingkat } \\
\text { Penguasaan }\end{array}$ & $\begin{array}{c}\text { Nilai } \\
\text { Huruf }\end{array}$ & Bobot & Predikat \\
\hline $86-100 \%$ & A & 4 & $\begin{array}{c}\text { Sangat } \\
\text { Baik }\end{array}$ \\
$76-85 \%$ & B & 3 & Baik \\
$60-75 \%$ & C & 2 & Cukup \\
$55-59 \%$ & D & 1 & $\begin{array}{c}\text { Kurang } \\
\leq 54 \%\end{array}$ \\
& TL & 0 & $\begin{array}{c}\text { Kurang } \\
\text { Sekali }\end{array}$ \\
\hline
\end{tabular}

Demikian pula jika nilai-nilai persen itu akan diubah menjadi nilai dengan skala 1 - 10 tinggal membagi nilai itu dengan angka 10, kemudian dibulatkan menurut ketentuan pembulatan angka desimal.

Pada pertemuan akhir juga, tim dan staf Pusat Pelatihan Akuntansi menyebarkan angket kepada peserta pelatihan akuntansi untuk mengukur tingkat kepuasan mereka setelah selesai mengikuti pelatihan akuntansi. Berikut hasil pengolahan data tingkat kepuasan peserta pelatihan akuntansi berdasarkan 10 indikator, antara lain : Tabel 4. Tingkat Kepuasan Peserta Pelatihan Akuntansi

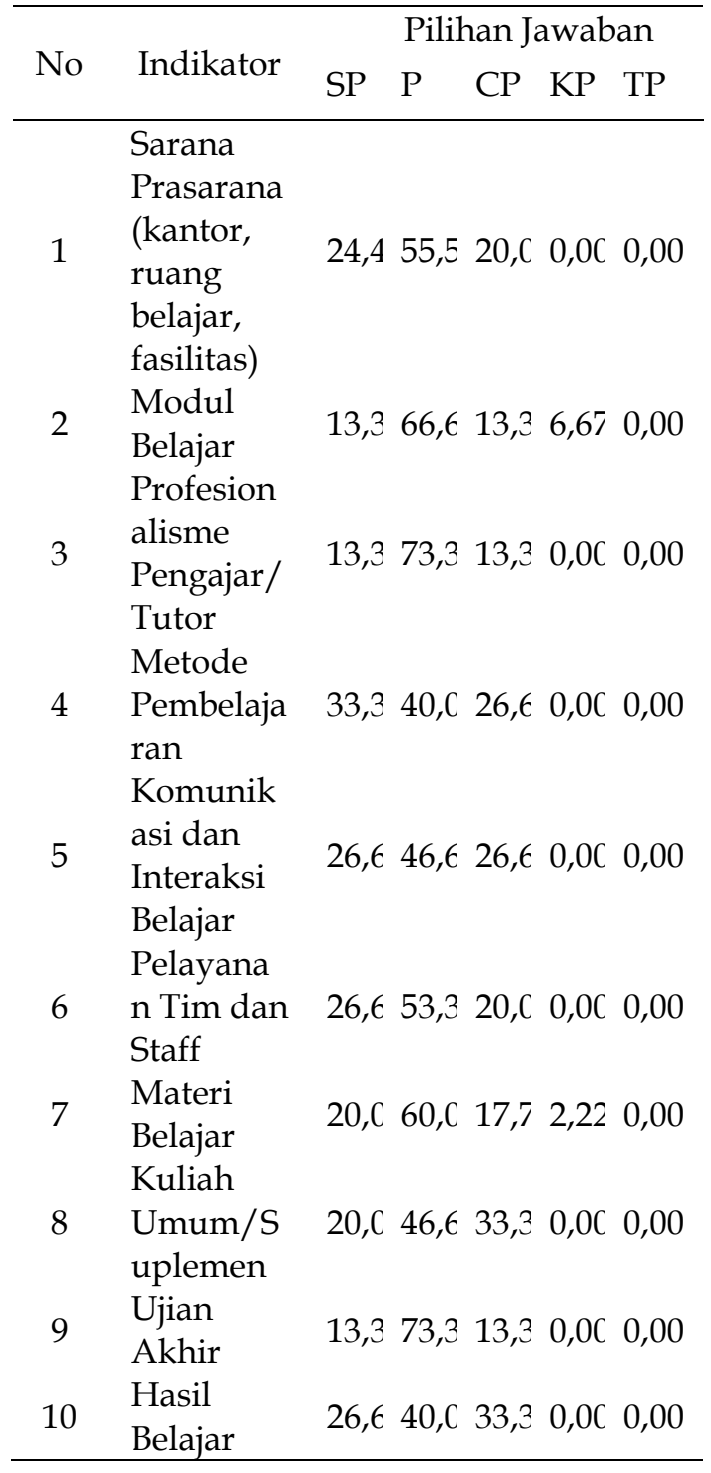

Dari data di atas, rata-rata 22,22 persen mengaku sangat puas, ratarata 56,00 persen mengaku puas dan sebanyak 20,89 persen mengaku cukup puas. Namun demikian tidak dapat dipungkiri ada sebagian kecil yang merasa kurang puas, yaitu sebanyak 0,89 persen mengaku 
kurang puas. Tidak ada peserta pelatihan yang mengaku tidak puas atas 10 indikator tingkat kepuasan setelah mengikuti pelatihan akuntansi tersebut.

Pada pertemuan akhir berupa ujian akhir bagi peserta pelatihan akuntansi juga dijadikan sebagai arena lomba akuntansi sesama peserta. Pemilihan dan penentuan pemenang lomba berdasarkan pemeringkatan hasil ujian akhir peserta. Adapun daftar pemenang (juara 1 sampai 3) pada setiap level/kelas berdasarkan gelombang masing masing sebagaimana tabel di bawah ini. Berikut ini daftar pemenang lomba akuntansi untuk gelombang 1 :

Tabel 5. Daftar Juara Lomba Akuntansi Gelombang 1

Kelas/Level : Akuntansi Perusahaan Jasa

\begin{tabular}{ccc}
\hline Juara & Nama & Asal Sekolah \\
\hline \multirow{3}{*}{1} & Annisa & SMA Negeri 19 \\
2 & Gebiolantina & Palembang \\
& Rifatul Meiliza & MAN 1 Palembang \\
3 & Choiriyah & MAN 1 Palembang \\
\hline
\end{tabular}

\begin{tabular}{ccc}
\multicolumn{3}{c}{$\begin{array}{c}\text { Kelas/Level : Akuntansi Perusahaan } \\
\text { Dagang }\end{array}$} \\
\hline \multirow{3}{*}{1} & Ine Sintia & SMK Muhammadiah \\
& Untari Syafitri & SMK Bina Jaya \\
& Undembang \\
2 & Hidayat & Palembang \\
& & SMK Bina Jaya \\
3 & Nurabayati & Palembang \\
\hline
\end{tabular}

Kelas/Level : Akuntansi Komputer

\begin{tabular}{|c|c|c|}
\hline 1 & Mitra Anggela & $\begin{array}{l}\text { SMK Muhammadiah } \\
2 \text { Palembang } \\
\text { SMK Negeri } 8\end{array}$ \\
\hline 2 & Ayu Andira & Palembang \\
\hline 3 & $\begin{array}{l}\text { Meyra Adelia } \\
\text { Effendi }\end{array}$ & $\begin{array}{l}\text { SMK Negeri } 8 \\
\text { Palembang }\end{array}$ \\
\hline
\end{tabular}

Selanjutnya berikut daftar pemenang lomba akuntansi untuk peserta pelatihan akuntansi pada gelombang 2:

Tabel 6. Daftar Juara Lomba Akuntansi Gelombang 2

Kelas/Level : Akuntansi Perusahaan

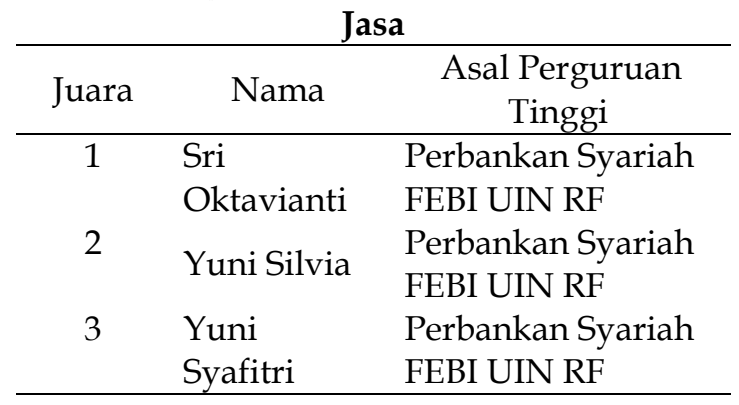

Kelas/Level : Akuntansi Perusahaan Dagang

\begin{tabular}{cll}
\hline 1 & Antiarni & Pendidikan \\
& Laras & Akuntansi FKIP \\
& Nawang & UPGRI \\
& Sari & \\
2 & Dandi & Pendidikan \\
& Kurniawan & Akuntansi FKIP \\
& & UPGRI \\
3 & Dwi & Pendidikan \\
& Susanti & Akuntansi FKIP \\
& Anggraini & UPGRI \\
\hline
\end{tabular}

Kelas/Level : Akuntansi Perusahaan Manufaktur

\begin{tabular}{cll}
\hline & Eni & Pendidikan Ekonomi \\
1 & Masitoh & FKIP UNSRI \\
& Ayu & Pendidikan Ekonomi \\
2 & Maulidina & FKIP UNSRI \\
& Nurul & Pendidikan Ekonomi \\
3 & Falah & FKIP UNSRI \\
\hline
\end{tabular}

Kelas/Level : Akuntansi Komputer

\begin{tabular}{cll}
\hline & Rivaldi & Pendidikan Ekonomi \\
1 & $\begin{array}{l}\text { Karunia } \\
\text { Abdi }\end{array}$ & FKIP UNSRI \\
& $\begin{array}{l}\text { Mariska } \\
\text { Wahdania }\end{array}$ & Akuntansi FE UNSRI \\
& Nely & \\
3 & Lestari & Akuntansi FE UPGRI \\
\hline
\end{tabular}


5. Bidang Instruktur dan Asisten: Nurastuti

Bidang instruktur dan asistem telah dapat bekerjasama dengan berbagai pihak sebagi pengajar dan/atau asistem pengajar. Adapuntim Pengajar dari dosen Prodi Pendidikan Akuntnsi FKIP Universitas PGRI, pengajar dari dosen Program Studi Akuntansi Fakultas Ekonomi (FE) Universitas PGRI Palembang.

Sedangkan tim pengajar mahasiswa Pengajar Pendamping /Asisten dengan prestasi akademik yang tinggi (IPK $\geq 3,5)$. Untuk
Tutor/Instruktur Alumni Prodi Pendidikan Akuntansi FKIP Universitas PGRI Palembang (yang Lulus dg Cum Laude). Selanjutnya untuk Tutor/Instruktur Tamu dan pembicara yang telah dilaksanakan hingga gelombang 2 yang berasal dari eksternal kampus adalah : Kgs. Abdul Rahman, SE (Kantor Pelayanan Pajak Pratama Ilir Timur Palembang) dan Dr. Maya Panorama, M.Si, Ph.D (Dosen Fakultas Ekonomi dan Bisnis Islam/FEBI UIN Raden Fatah Palembang).

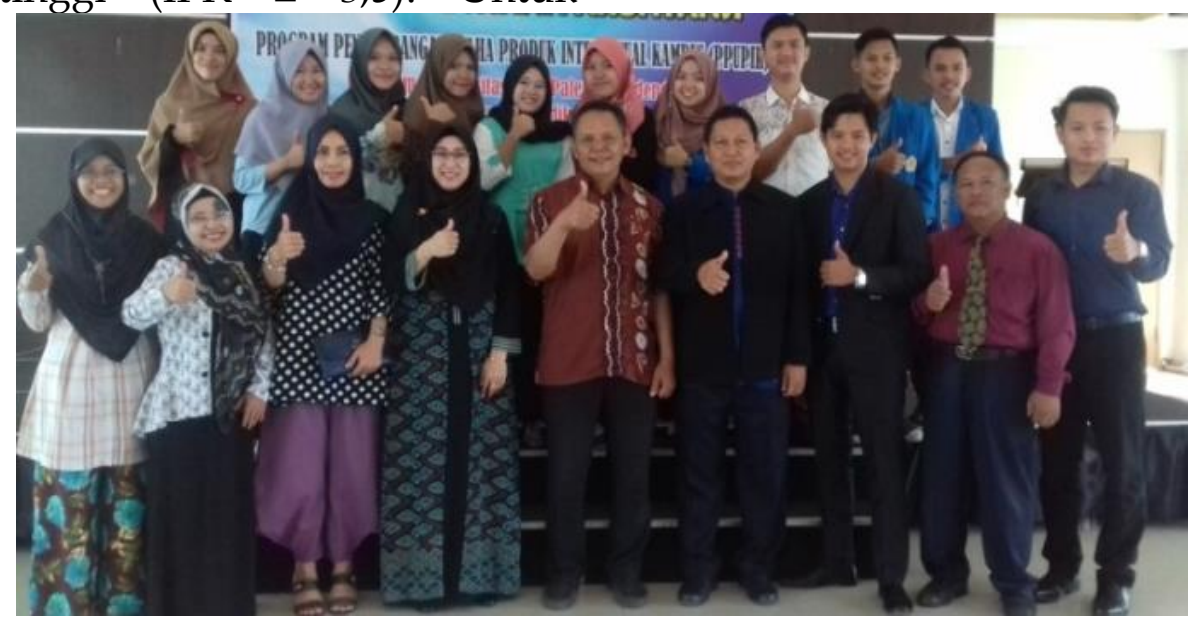

Gambar 7. Tim Pengajar (instruktur dan asisten) Pusat Pelatihan Akuntansi

\section{KESIMPULAN}

Dari hasil dan pembahasan di atas, maka dapat ditarik kesimpulan antara lain :

a. Pelaksanaan kegiatan pelatihan akuntansi yang telah dilakukan dengan dua kelas yaitu kelas pagi jam belajar 08.00 - 12.00 WIB. Sedangkan kelas siang jam belajar 12.00 - 16.00 WIB. Pelatihan akuntansi yang dilakukan dibagi ke dalam 4 kelas, yaitu akuntansi perusahaan jasa, akuntansi perusahaan dagang, akuntansi perusahaan manufaktur dan akuntansi komputer $(M Y O B$ dan Accurate).

b. Pada gelombang 1 (Februari Maret 2018) pesertanya pelajar SMA, SMK dan MA yang berjumlah 149 orang, pada gelombang 2 (Mei - Juni 2018) pesertanya mahasiswa dari berbagai perguruan tinggi yang berjumlah 149 orang dan pada gelombang 3 (Agustus September 2018) pesertanya adalah siswa SMA, SMK dan MA 
yang berjumlah 50 orang. Setelah menempuh pembelajaran 12-16 pertemuan dilaksanakan ujian akhir, bagi yang dinyatakan lulus diberikan sertifikat.

\section{DAFTAR PUSTAKA}

Astuti P D. 2012. Akuntansi Keuangan Dasar 1, Teori $\mathcal{E}$ Kasus. Yogyakarta: CAPS, 87-198.

Haryono B, et al. 2018. Pemahaman Siswa atas Prinsip-Prinsip Kewirausahaan dan Keuangan : Suatu studi kasus di SMK Mahanaim Bekasi. Prosiding Seminar Nasional Hasil Pengabdian kepada Masyarakat SENDIMAS 2018 Unkrida Jakarta., 451-454.

Juanda. 2011. Evaluasi Program Diklat Prajabatan Golongan III. Jurnal Evaluasi Pendidikan Universitas Negeri Jakarta, 2 (1): 31-41.

Mursyidi. 2010. Akuntansi Dasar. Bogor: Penerbit Ghalia Indonesia, 146-150 dan 211-217.

Murwaningsih T. 2013. Model Pendidikan Karakter Berkelanjutan bagi Mahasiswa LPTK. Jurnal Pemikiran dan Penelitian Pendidikan Tinggi Akademika LPP Universitas Sebelas Maret, 5 (2) : 91-96.

Permendikbud Republik Indonesia Nomor 69 Tahun 2013 tentang Kerangka Dasar dan Struktur Kurikulum Sekolah Menengah Atas/Madrasah Aliyah

Permendikbud Republik Indonesia Nomor 70 Tahun 2013 tentang Kerangka Dasar dan Struktur
Kurikulum Sekolah Menengah Kejuruan/Madrasah Aliyah Kejuruan.

Prajitno S. 2009. Komputer Akuntansi dengan MYOB Accounting. Bogor: Penerbit Ghalia Indonesia: 68143.

Samryn. 2012. Pengantar Akuntansi, Mudah Membuat Jurnal dengan Pedekatan Siklus Transaksi. Jakarta: Raja Grafindo Persada: 249-433.

Sodikin S S. Bogat Agus Riyono. 2012. Akuntansi Pengantar 1 Edisi Kedelapan. Yogyakarta: Unit Penerbitan dan Percetakan STIM YKPN, 277 - 297.

Undang-Undang Republik Indonesia Nomor 20 Tahun 2003 tentang Sistem Pendidikan Nasional.

Undang-Undang Republik Indonesia Nomor 14 tahun 2005 tentang Guru dan Dosen

Peraturan Pemerintah Republik IndonesiaNomor 19 Tahun 2005 tentang Standar Nasional Pendidikan

Wijayanti P H, et al. 2013. Model Evaluasi Pembelajaran Berbasis Kaizen di Sekolah Menengah Atas. Jurnal Penelitian dan Evaluasi Pendidikan, 17 (2) : 318332.

Yadiati W dan Ilham W. 2010. Pengantar Akuntansi, Edisi Revisi. Jakarta: Kencana Prenada Media Group: 65-111. 